\section{Nauplius}

The Journal OF THE Brazilian Crustacean Society

e-ISSN 2358-2936

www.scielo.br/nau www.crustacea.org.br

\title{
New species of Acanthochondria Oakley, 1930 and Chondracanthus Delaroche, 1811 (Copepoda: Cyclopoida: Chondracanthidae) parasitizing marine fishes from Indian waters
}

\author{
Panakkool Thamban Aneesh (D) orcid.org/0000-0002-8506-5107
}

Ameri Kottarathil Helna (D) orcid.org/0000-0003-0659-2169

Appukuttannair Biju Kumar (D) orcid.org/0000-0001-5477-2119

\author{
Department of Aquatic Biology \& Fisheries, University of Kerala, Karyavattom, \\ Thiruvananthapuram-695 581, Kerala, India. \\ ZOOBANK: http://zoobank.org/urn:lsid:zoobank.org:pub:D504FAB8-5F1C-49B1- \\ 9473-E316B0002CBA
}

\begin{abstract}
This paper describes two new species of parasitic copepods of the family Chondracanthidae H. Milne Edwards, 1840. Acanthochondria krishnai sp. n. is described from Dollfus' stargrazer, Uranoscopus guttatus Cuvier, collected from Muttom and Colachel, Tamil Nadu, and Chondracanthus kabatai sp. n. from Silvery john dory, Zenopsis conchifer Lowe, collected from Neendakara, Quilon, Kerala, both along the southwest coast of India. Both the species are described and illustrated based on the fresh female and male specimens collected from India. Both the species are the first Indian representative of the respective genera. The checklist of Indian species of the family Chondracanthidae is also presented.
\end{abstract}

\section{KeYwords}

Chondracanthids, Chondracanthus kabatai sp. n., Zenopsis conchifer, Acanthochondria krishnai sp. n., Uranoscopus guttatus, Checklist.

\section{INTRODUCTION}

The family Chondracanthidae H. Milne Edwards, 1840 is composed of

CORRESPONDING AUTHOR Panakkool Thamban Aneesh anee3716@gmail.com

SUBMITTED 1 September 2019 ACCEPTED 16 March 2020 PUBLISHED 03 June 2020

DOI 10.1590/2358-2936e2020014

\section{(cc) BY}

All content of the journal, except where identified, is licensed under a Creative Commons attribution-type BY.

Nauplius, 28: e2020014 
remains little studied in India, with only nine species belonging to the five genera described thus far, without any representatives from the genera Acanthochondria and Chondracanthus.

The parasitic copepod fauna infesting the commercial fishes are comparatively well studied in India, especially from the southwest coast. The families such as Bomolochidae, Caligidae, Ergasilidae, Lernaeopodidae, Lernanthropidae, Pandaridae, Pennellidae, and Taeniacanthidae are well documented (Gnanamuthu, 1953; Rangnekar, 1960; Sebastian, 1967; Pillai, 1985), while the family Chondracanthidae is less studied. Pillai (1985) recorded five species of chondracanthids, viz., Bactrochondria hoi (Pillai, 1985) (described as Ceratochondria hoi), Heterochondria pillaii Ho, 1970; Medesicaste penetrans Heller, 1868; Protochondracanthus alatus (Heller, 1868) and $P$. trilobatus (Pillai, 1964). Later Ho et al. (2000) added a new genus and four species including three new species (viz., Heterochondria petila Ho, Kim and Kumar, 2000, Bactrochondria papilla Ho, Kim and Kumar, 2000, and Acanthochondria zebriae [= Heterchondria zebriae (Ho, Kim and Kumar, 2000); transferred by Tang et al., 2010] and a new genus, Bactrochondria Ho, Kim and Kumar, 2000. Recently Kizhakudan et al. (2015) reported P. alatus from the captive stock of Psettodes erumi (Bleeker and Schneider). The total number of species of chondracanthids thus far recorded from India is only nine.

In the present study two new species (Acanthochondria krishnaisp. n. and Chondracanthus kabataisp. n.) collected from three fish landing centers from the southwest coast of India are described, with a review on Indian species of the family Chondracanthidae.

\section{Materials and Methods}

Fresh specimens of chondracanthids were collected from three fish landing centers on the southwest coast of India, namely Muttom and Colachel (Kanyakumari district, Tamil Nadu coast) ( $\left.8^{\circ} 07^{\prime} 48.00^{\prime \prime} \mathrm{N} 77^{\circ} 19^{\prime} 12.00^{\prime} \mathrm{E}\right)$ and Neendakara $\left(08^{\circ} 30.0^{\prime} \mathrm{N} 76^{\circ} 53.30^{\prime} \mathrm{E}\right)$, Quilon district, Kerala coast. The chondracanthids were collected from the host fish, fixed in 5\% formaldehyde, preserved in 75\% ethanol (after Aneesh et al., 2018) and subjected to identification. Methods for dissection, mounting, and drawings of appendages were according to the techniques described in Aneesh et al. (2018). Drawings were digital inked using Adobe Illustrator and WACOM CTL-472/K0-c drawing pad. The specimens were microphotographed using multifocusing dissection microscope Leica-M205A and image capturing software (Leica Application Suit). Morphological details of the parasite were also examined using a scanning electron microscope (Zeiss EVO 18 SEM). Fish taxonomy and host nomenclature were performed according to FishBase (Froese and Pauly, 2020). The types and voucher specimens are deposited in the Western Ghat Field Research Centre of Zoological Survey of India, Kozhikode (ZSI/WGRC).

\section{TAXONOMY}

\section{Order Cyclopoida Burmeister, 1834}

\section{Family Chondracanthidae Edwards, 1840}

Genus Acanthochondria Oakley, 1930

Type species. Acanthochondria cornuta (Müller O.F., 1776) (by original designation).

\section{Acanthochondria krishnai sp.n.}

(Figs. 1-6)

Zoobank: urn:1sid:zoobank.org:act:F26FCD3BA7DC-45E3-AE42-F8B9D0ED693A

Material examined: 23 females (16 ovigerous), all with immature/mature males.

Type material. Holotype: 1 female $(17 \mathrm{~mm})$ (ZSI/ WGRC/IR/INV/11733), from Uranoscopus guttatus Cuvier, from Muttom, southwest coast, India, coll. P.T. Aneesh on 17 March 2018. — Paratypes: same information as holotype, 1 female $(15 \mathrm{~mm})$ (ZSI/ WGRC/IR/INV/ 11734; 1 male $(0.5 \mathrm{~mm})(\mathrm{ZSI} /$ WGRC/IR/INV/14048). 


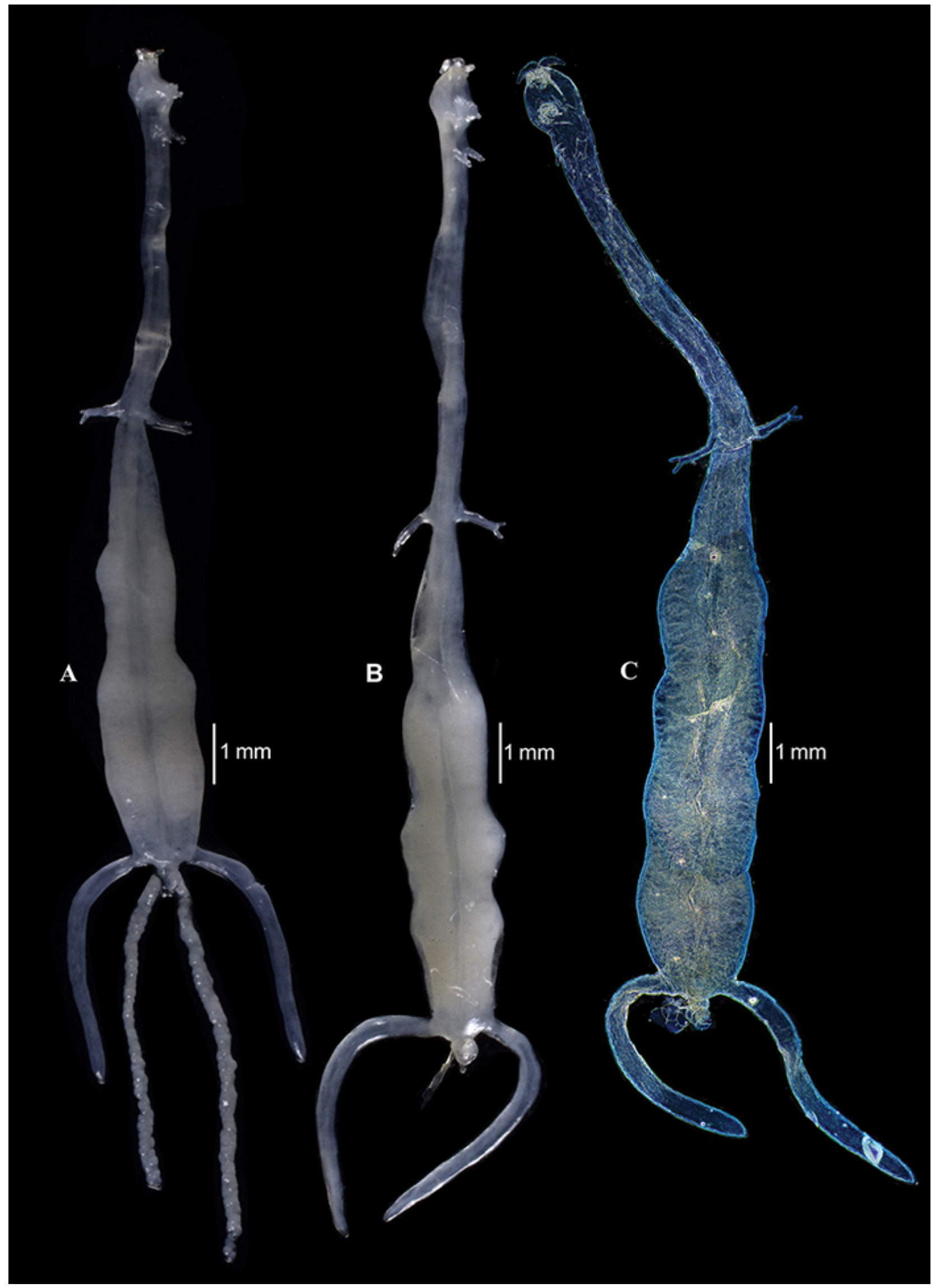

Figure 1. Acanthochondria krishnai sp. n., female from Uranoscopus guttatus Cuvier. A, B. Dorsal view. C. Ventral view. 


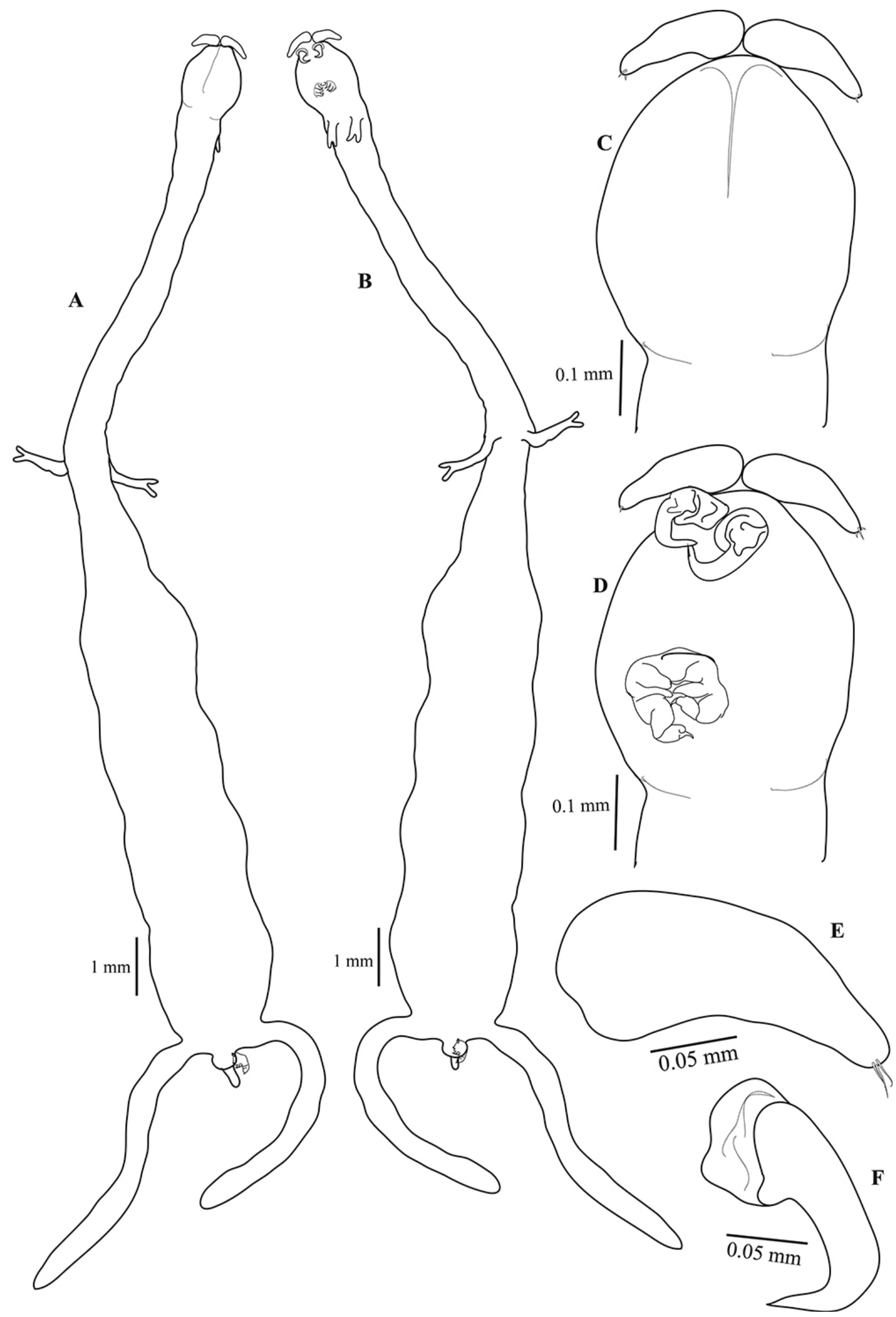

Figure 2. Acanthochondria krishnai sp. n., holotype, female from Uranoscopus guttatus Cuvier. A. Dorsal view. B. Ventral view. C, D. Cephalon, dorsal and ventral views. E. Antennule. F. Antenna. 

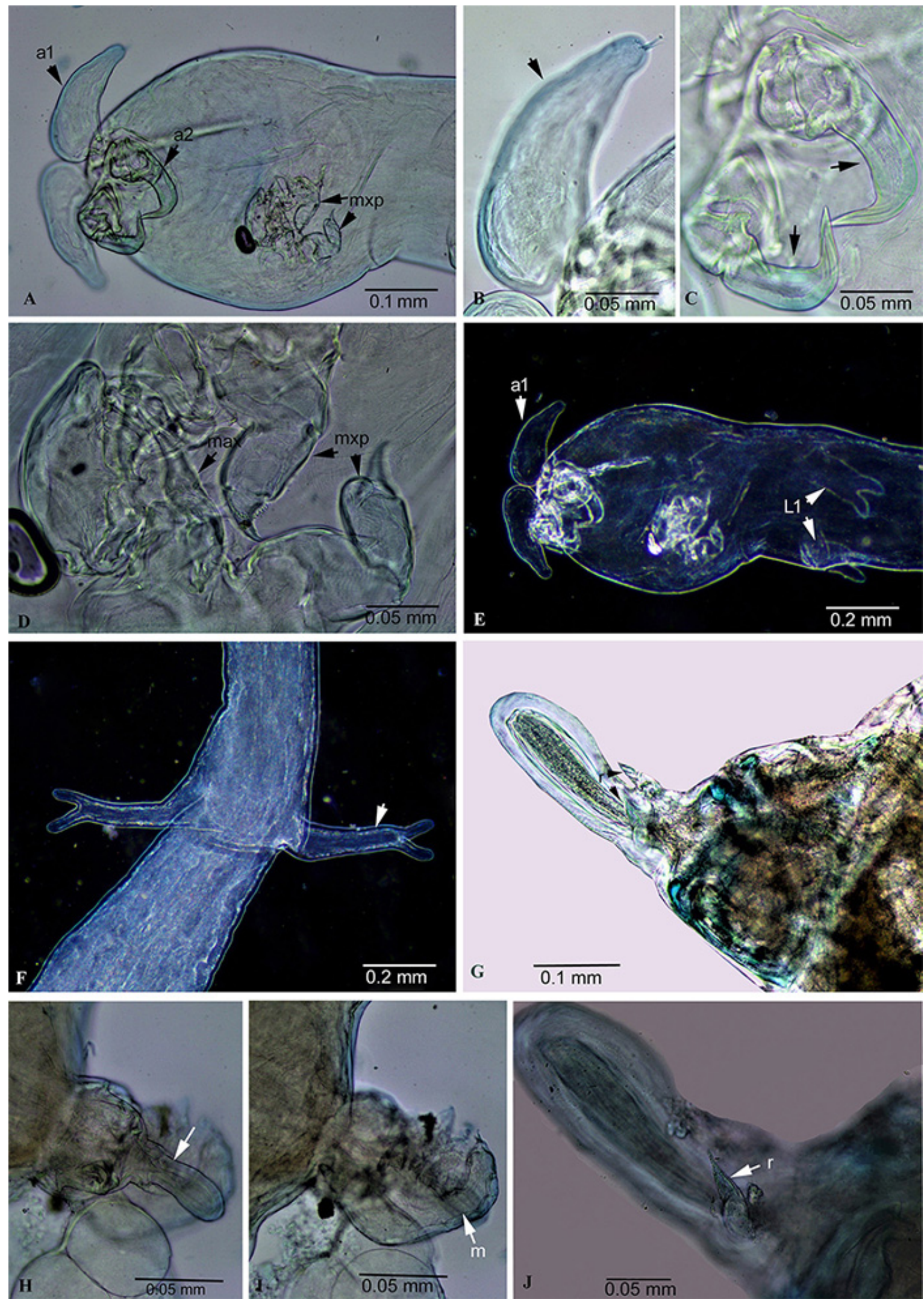

Figure 3. Acanthochondria krishnai sp. n., non-type female from Uranoscopus guttatus Cuvier. A. Cephalon ventral view showing cephalic appendages. B. Antennule (arrow). C. Antennules (arrows). D. Cephalic appendages. E. Leg 1. F. Leg 2. G-J. Genitoabdomen. G. Lateral view with rami. H. Ventral view with rami. I. Dorsal view with male. J. With rami. (a1- antennule, a2- antenna, mxp- maxilliped, max- maxilla; L1- leg 1, L2- leg 2, m- male, r- rami). 


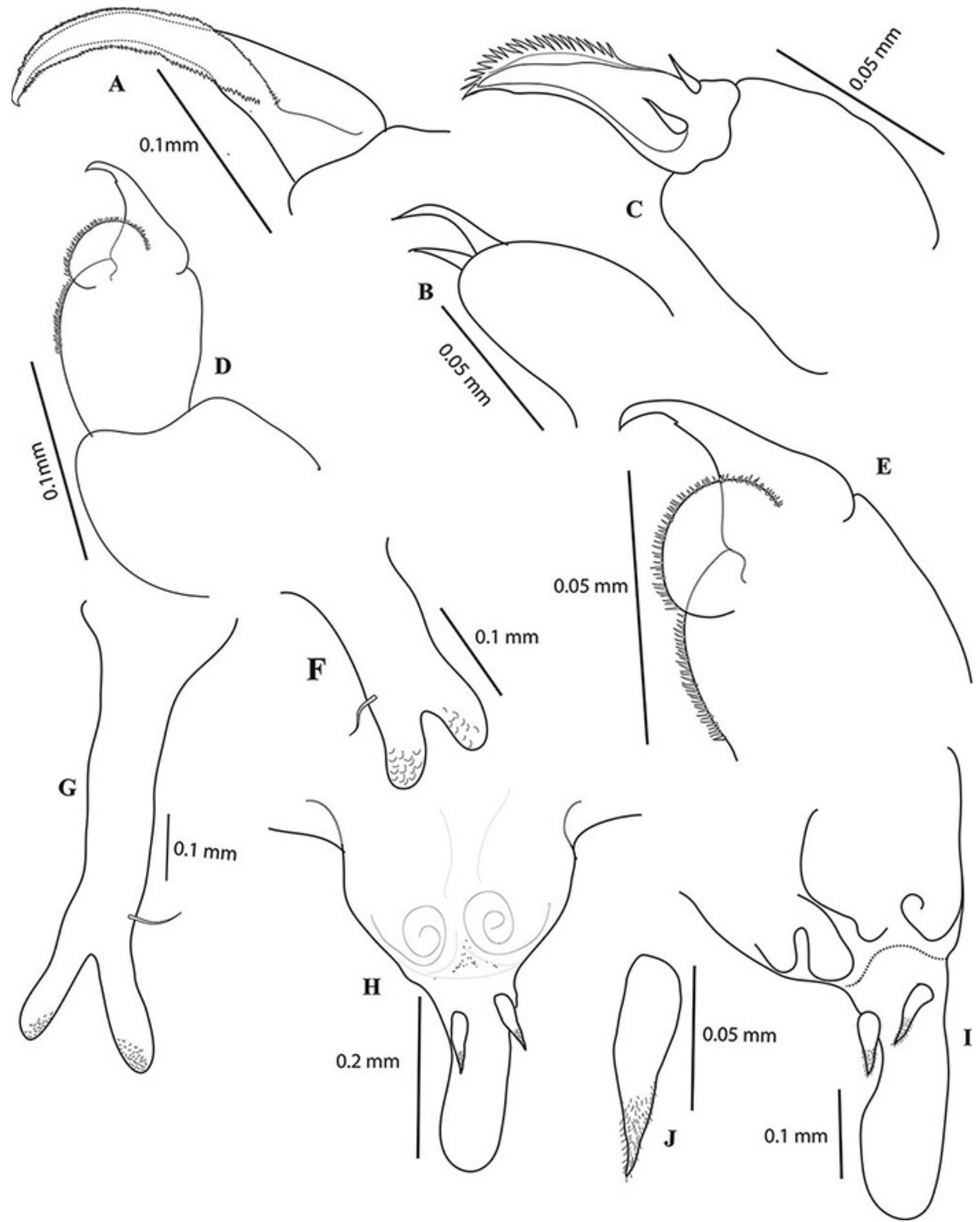

Figure 4. Acanthochondria krishnai sp. n., paratype, female from Uranoscopus guttatus Cuvier. A. Mandible. B. Maxillule. C. Maxilla. D. Maxilliped. E. Maxilliped apex. F. Leg 1. G. Leg 2. H, I. Genito-abdomen with rami, ventral and ventro-lateral views. J. Rami. 
Description. Female (Figs. 1-4): Body long and slender (16-18 $\mathrm{mm}$ ) (excluding egg strings; from anterior margin of head to distal end of posterior processes), divisible into short head, much elongated neck, stout trunk with prominent constrictions on posterior half, as long as neck, bearing a pair of posterior processes, small genito-abdomen and abdomen with the prominent process which extends to the posterior tip of caudal rami. Cephalon, small, 1.2 times longer than wide, attached to neck; posteroventral region swollen, with mouthparts. Neck greatly elongated $(8-9 \mathrm{~mm})$ and gradually jointed into trunk. Trunk as long as neck, postero lateral margin with pair of long processes $(4-5.5 \mathrm{~mm})$ directed laterally, posterolaterally, or posteriorly. Genito-abdomen (0.45-0.5 $\mathrm{mm}$, long; total length including the median projection, the abdomen), funnel-shaped, longer than wide, basally wider $(0.28-0.30 \mathrm{~mm}$ wide), with median projection (the abdomen) (0.25-0.28 $\mathrm{mm}$ long and $0.06 \mathrm{~mm}$ wide) gradually narrowing posteriorly, with curved apex. Genital complex with pair of setules in midventral region bearing egg strings.
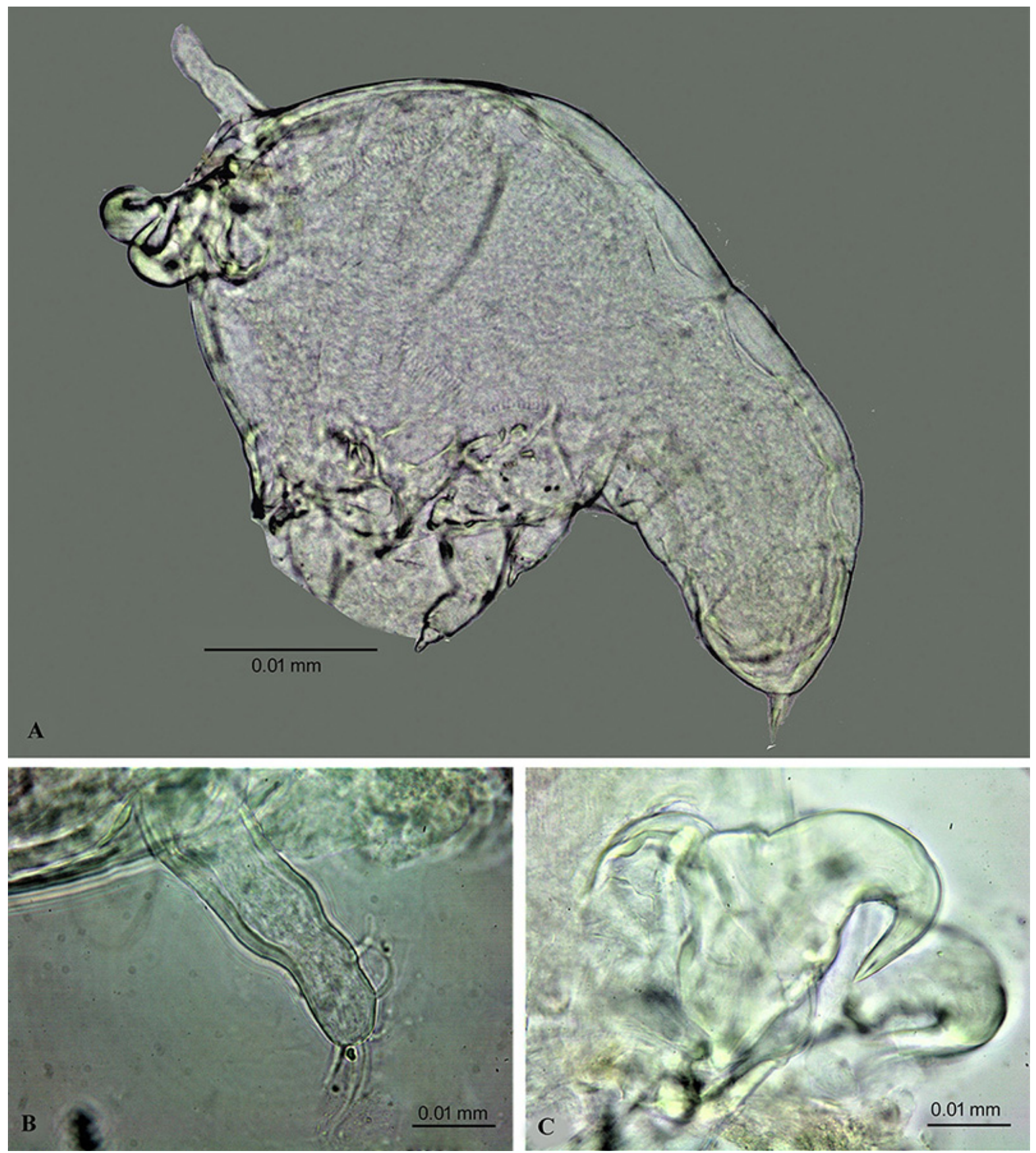

Figure 5. Acanthochondria krishnai sp. n., non-type male from Uranoscopus guttatus Cuvier. A. Habitus lateral view. B. Antennule. C. Antenna. 


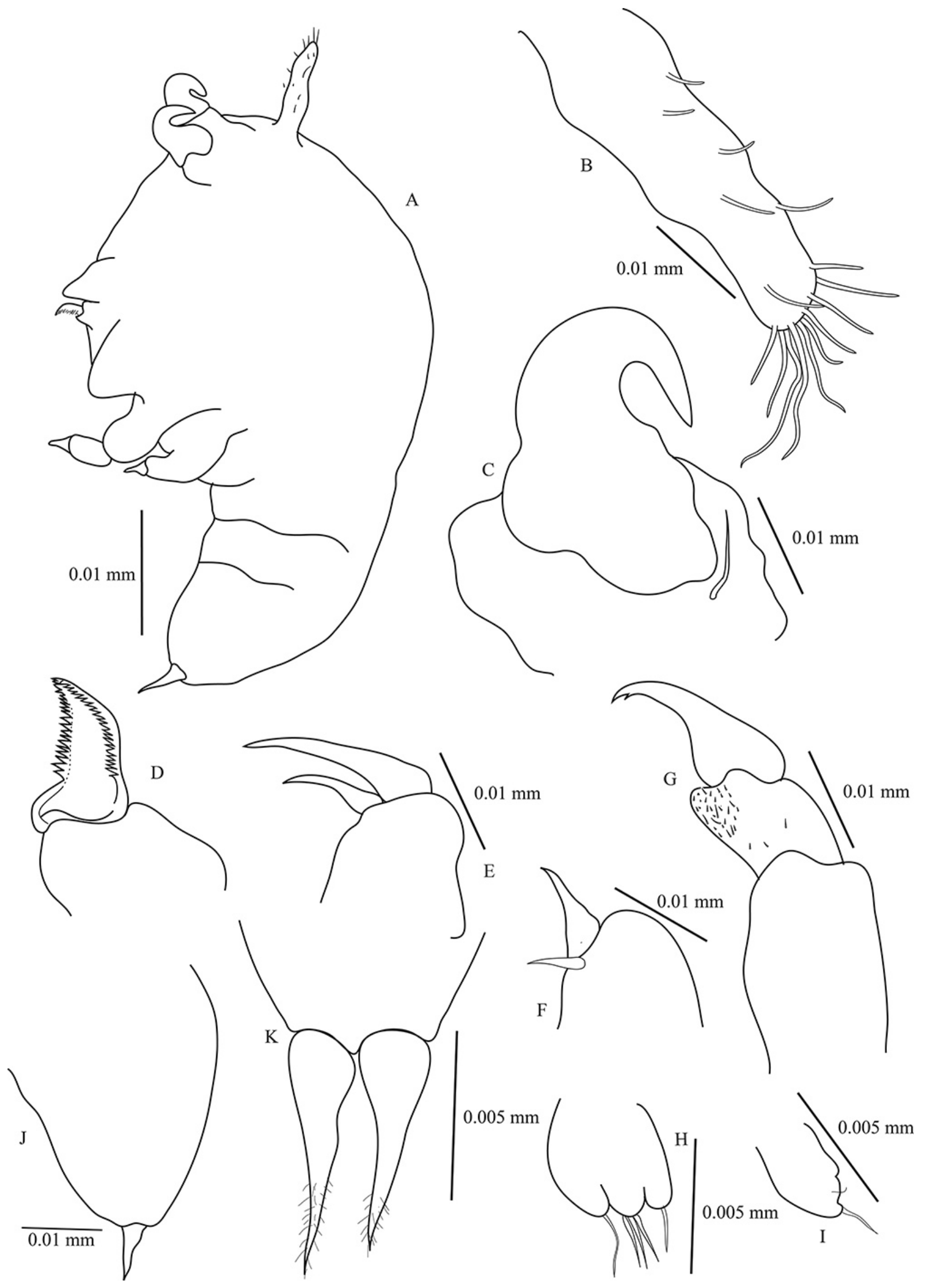

Figure 6. Acanthochondria krishnai sp. n., non-type male from Uranoscopus guttatus Cuvier. A. Habitus lateral view. B. Antennule. C. Antenna. D. Mandible. E. Maxillule. F. Maxilla. G. Maxilliped. H. Leg 1. I. Leg 2. J. Lateral view of genito-abdomen. K. Ventral view of genito-abdomen. 
Egg strings cylindrical, not coiled and longer than trunk; eggs multiseriate. Number of eggs per string ranged from 170 to 240, dependent on length of the string. Genital complex carrying pair of conical rami with numerous spinules on terminal portion.

Antennule cylindrical and fleshy, without division, basally swollen, and distally slender with few terminal setae. Antenna, usual form with heavily sclerotized and unarmed basal segment and strongly curved, pointed terminal claw. Mandible with many teeth (55-60) on convex side and 40-44 teeth on concave side. Maxillule with spinulose inner-terminal surface; distal margin with 2 unequal setae. Two-segmented maxilla; first segment greatly broad and unarmed; terminal segment with more or less equal robust seta in basal region, and the outer margin claw-like, armed with row of 28-32 denticles. Maxilliped 3-segmented; first segment stout, largest, unarmed; second segment with two patches of denticles on medial surface and protruded medio-distal corner, partially overlapping base of the distal segment; terminal segment ending in curved claw-like structure with small, sub-terminal hooklet on inner surface. Legs biramous, protopod with one seta, leg $1(0.25 \mathrm{~mm})$; both rami bearing spinules/pectinate scales on terminal portion. Leg 2 $(0.4 \mathrm{~mm})$ much longer than (1.8 times) leg 1.

Male (Figs. 5-6): Body, $0.45 \mathrm{~mm}$ long (excluding caudal rami), $0.25 \mathrm{~mm}$ wide, ventrally curved, cephalothorax, more than half the length of total body. Metasome cylindrical, with indistinct metamerism. Genital segment with pair of ventral genital ridges. Caudal ramus similar to that of female.

Antennule elongated, with armature formula 2, $1,2,2$, and 8-9. Antenna, solid, robust and strongly curved, sharp claw; with seta on dorso-lateral surface. Mandible with 16-18 teeth on convex side and 12-14 teeth on concave side. Maxillule with 2 setae, more or less similar to female. Maxilla without teeth on terminal process. Maxilliped article 2 with few denticles. Legs bilobate, leg 1 larger than leg 2; with few long lateral setae, larger in leg 1 ; endopods reduced to lobes.

Body size: Female (15-18 mm); male (0.45-0.50 $\mathrm{mm})$.

Color: White after fixation.
Distribution: Known from Muttom (the type locality) and Colachel, Tamil Nadu coast, India; Neendakara, Quilon, Kerala coast, India.

Host: The type host Uranoscopus guttatus Cuvier.

Site of attachment: Attached to floor of oral cavity.

Etymology: This species is named in honor of late Prof. N. Krishna Pillai, Department of Aquatic Biology \& Fisheries, University of Kerala, an expert crustacean taxonomist from India, who has consolidated knowledge on parasitic copepods of marine fishes of India.

Genus Chondracanthus Delaroche, 1811

Type species: Chondracanthus zei Delaroche, 1811 (by original designation)

\section{Chondracanthus kabatai sp. n.}

(Figs. 7-14)

Zoobank: urn:1sid:zoobank.org:act:E317CB1AEB5B-4D91-A651-11F124C11168

Material examined: 37 females (30 ovigerous), all with immature/mature males.

Type material. Holotype: 1 female $(6.5 \mathrm{~mm})$ (ZSI/ WGRC/IR/INV/11728) from Zenopsis conchifer Lowe, Neendakara, Quilon, India, coll. P.T. Aneesh and A. Biju Kumar on 26 February 2018. - Paratypes: same information as holotype, 1 female $(8 \mathrm{~mm})$ (ZSI/ WGRC/IR/INV/11729); 1 male $(0.5 \mathrm{~mm})(\mathrm{ZSI} /$ WGRC/IR/INV/14049); 1 female $(8 \mathrm{~mm})(\mathrm{ZSI} /$ WGRC/IR/INV/11730); 1 female $(7.5 \mathrm{~mm})(\mathrm{ZSI} /$ WGRC/IR/INV/11731); 1 female $(8 \mathrm{~mm})(\mathrm{ZSI} /$ WGRC/IR/INV/11732).

Description. Female (Figs. 8-14): Body 4.8-8.0 $\mathrm{mm}$ length (without egg strings, from anterior margin of head to distal end of longest posterior processes on trunk), unsegmented, divisible into head, short neck, stout trunk and genito-abdomen. Cephalon having cephalosome, as long as wide, with two pairs of elongated and fusiform, pedunculate ventro-lateral processes, the second process about 1.8-2 times longer than process 1 . Cephalon dorsally bearing medial longitudinal sclerotized bar. Neck, short and narrow 
without processes. Trunk much broader, armed with elongated, narrow, fusiform processes; three pairs of anterior, three pairs of posterior and single posteriomedian. Anterior processes including (1) pair of dorsal (1.0-1.2 mm long), horn-like, on either side close to the lateral margin, directed forward; (2) pair of long (2.1-2.4 $\mathrm{mm}$ long), laterally directed, from the lateral margin; and (3) pair of much longer, bifurcate (outer one (3.1-3.2 $\mathrm{mm}$ long), inner one much longer (4.2-4.4 $\mathrm{mm}$ long)), from the ventral side near to either side of second pair of legs. Posterior processes including (1) pair of ventro-lateral, from the corner (3.5-3.7 mm long); (2) pair at posterior corner, much longer, trifurcate (outer one (3.3-3.4 mm long), middle (3.5-3.6 mm long), and inner (3.9-4.2 $\mathrm{mm}$ long)); (3) single, median processes (3.8-4.1 mm long) (much reduced in two specimens (Fig.9 c)) on dorsal side, apparently intersect the lateral processes; (4) a paired, long process on ventral surface (3.5-3.6 $\mathrm{mm}$ long), close to either side of median line, just above genito-abdomen. Genito-abdomen (0.25-0.3 $\mathrm{mm}$, long; $0.2 \mathrm{~mm}$ wide) globular, longer than wide. Genital complex with pair of setules in midventral region bearing egg strings. Abdomen 2 times wider than long ( $0.16 \mathrm{~mm}$ wide, $0.08 \mathrm{~mm}$ long). Caudal ramus conical, directed ventrally and armed with two ventral setae, one dorsal seta and apical conical spinulose papilla.

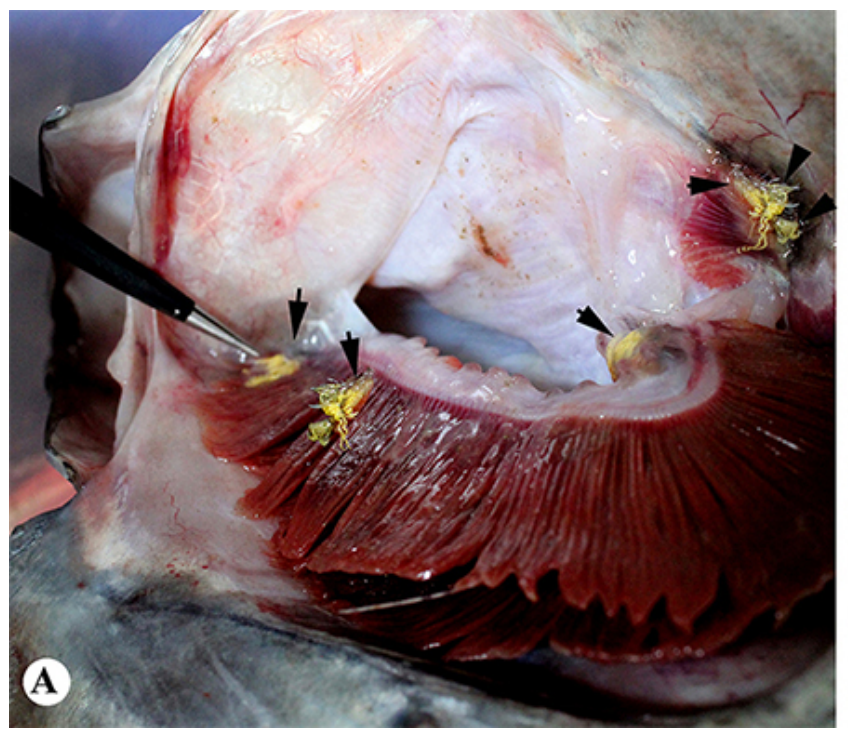

Egg strings cylindrical, yellow colored, irregularly coiled and extremely longer than trunk; eggs multiseriate. Number of eggs per string ranged from 370 to 440 , depending on length of the string.

Antennule, cylindrical, unsegmented and fleshy, basally swollen, and distally slender with few marginal setae, apex with 5-6 long and 2-3 short terminal setae. Antenna, usual form with unarmed basal segment; distal segment, strongly curved, heavily sclerotized, marked by band of transverse surface striations at the base, apex, pointed and curved terminal claw. Mandible, distal segment apically curved, with many teeth (118-124) on convex side and 80-86 teeth on concave side. Maxillule, lobate, tipped with two unequal apical spinules. Two-segmented maxilla; first segment unarmed; terminal segment with a robust seta in basal region, and the outer margin claw-like, armed with row of 16-22, 11-16 denticles. Maxilliped, 3 -segmented; first segment robust, unarmed; second segment with a patch of minute spinules on inner edge; distal segment, small, ending in curved claw-like structure with small, subterminal hooklet on inner surface. Legs biramous, both rami bearing spinules/ pectinate scales on terminal portion, protopod bearing outer seta. Leg 1 (0.7-0.9 mm long) slightly larger than leg 2 (0.6-0.7 mm long), situated ventrally on trunk region.

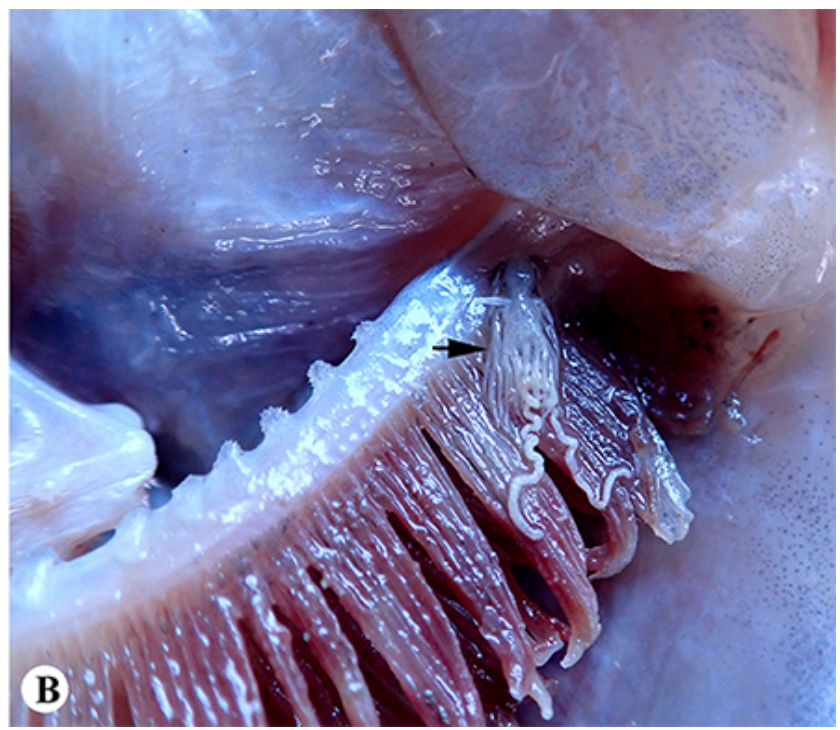

Figure 7. A, B. Site of attachment of Chondracanthus kabatai sp. n. (arrows) on its host fish Zenopsis conchifer Lowe. 


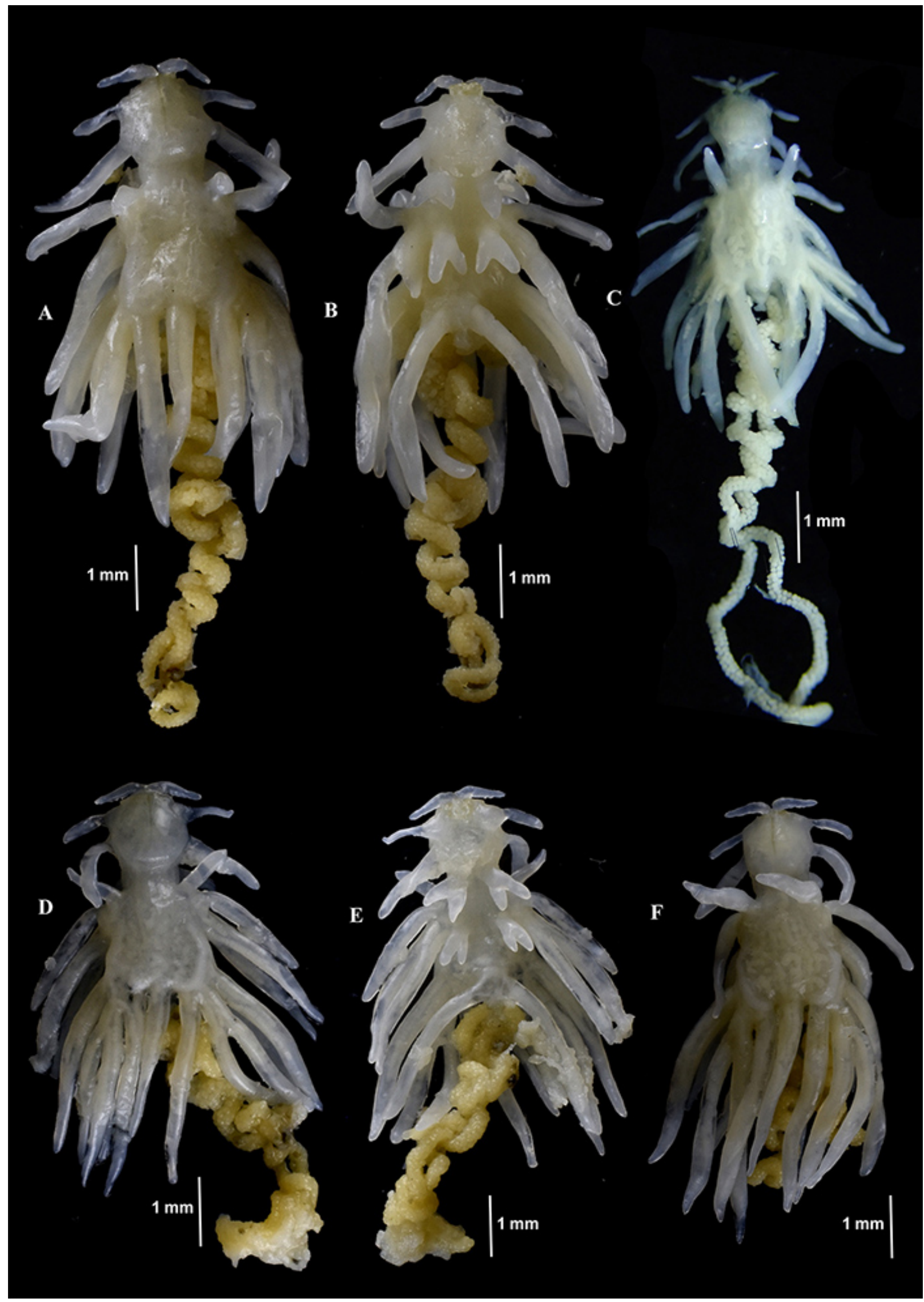

Figure 8. Chondracanthus kabatai sp. n. from Zenopsis conchifer Lowe. A-C. Holotype, female, dorsal, ventral and lateral views. D-F. Paratype, female, dorsal, ventral and dorso-lateral views. 

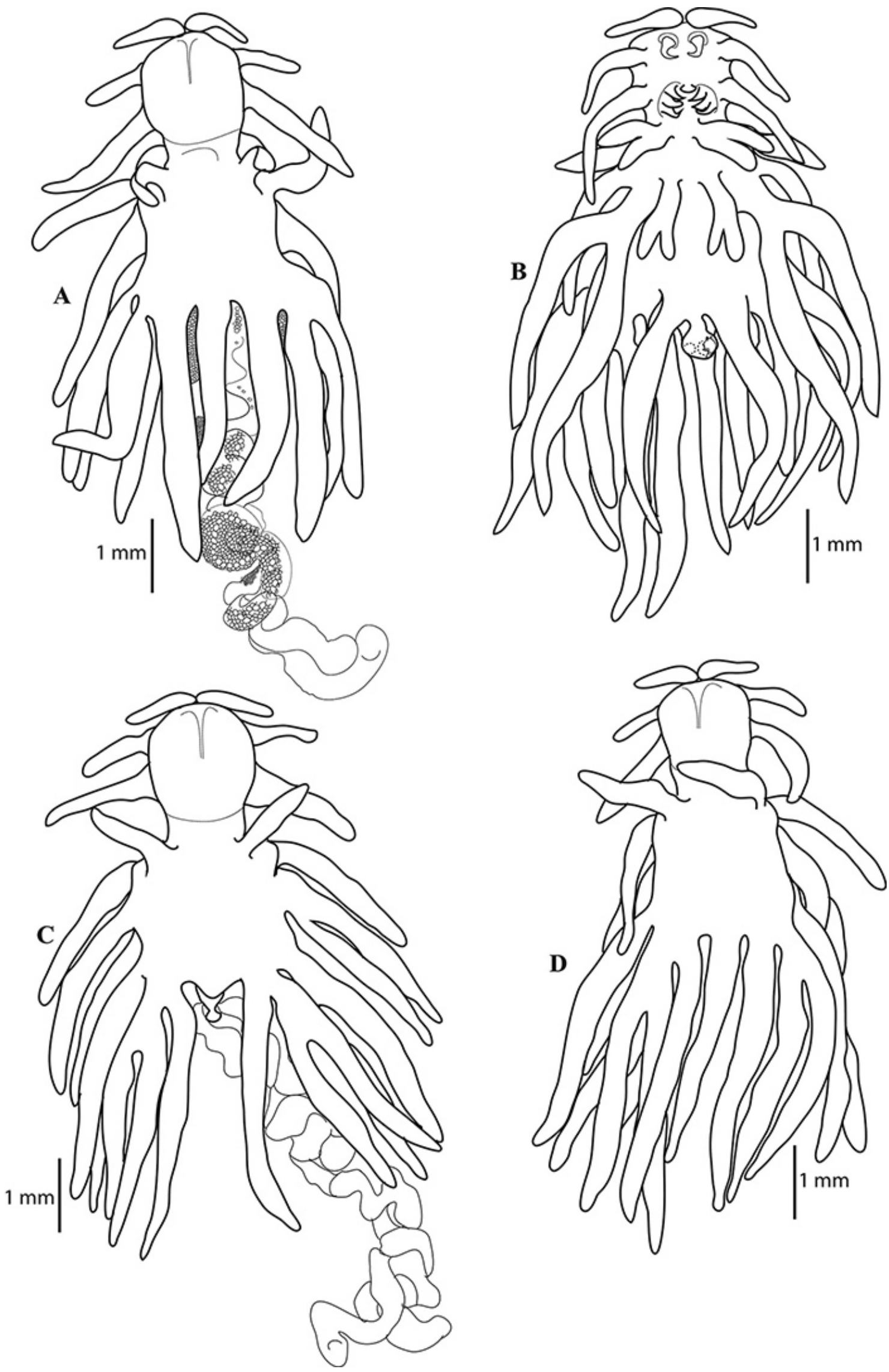

Figure 9. Chondracanthus kabatai sp. n. from Zenopsis conchifer Lowe. A, B. Holotype, female, dorsal and ventral view. C. Paratype, female (ZSI/WGRC/IR/INV/11732), dorsal view, D. Paratype, female (ZSI/WGRC/IR/INV/11729), dorso-lateral view. 

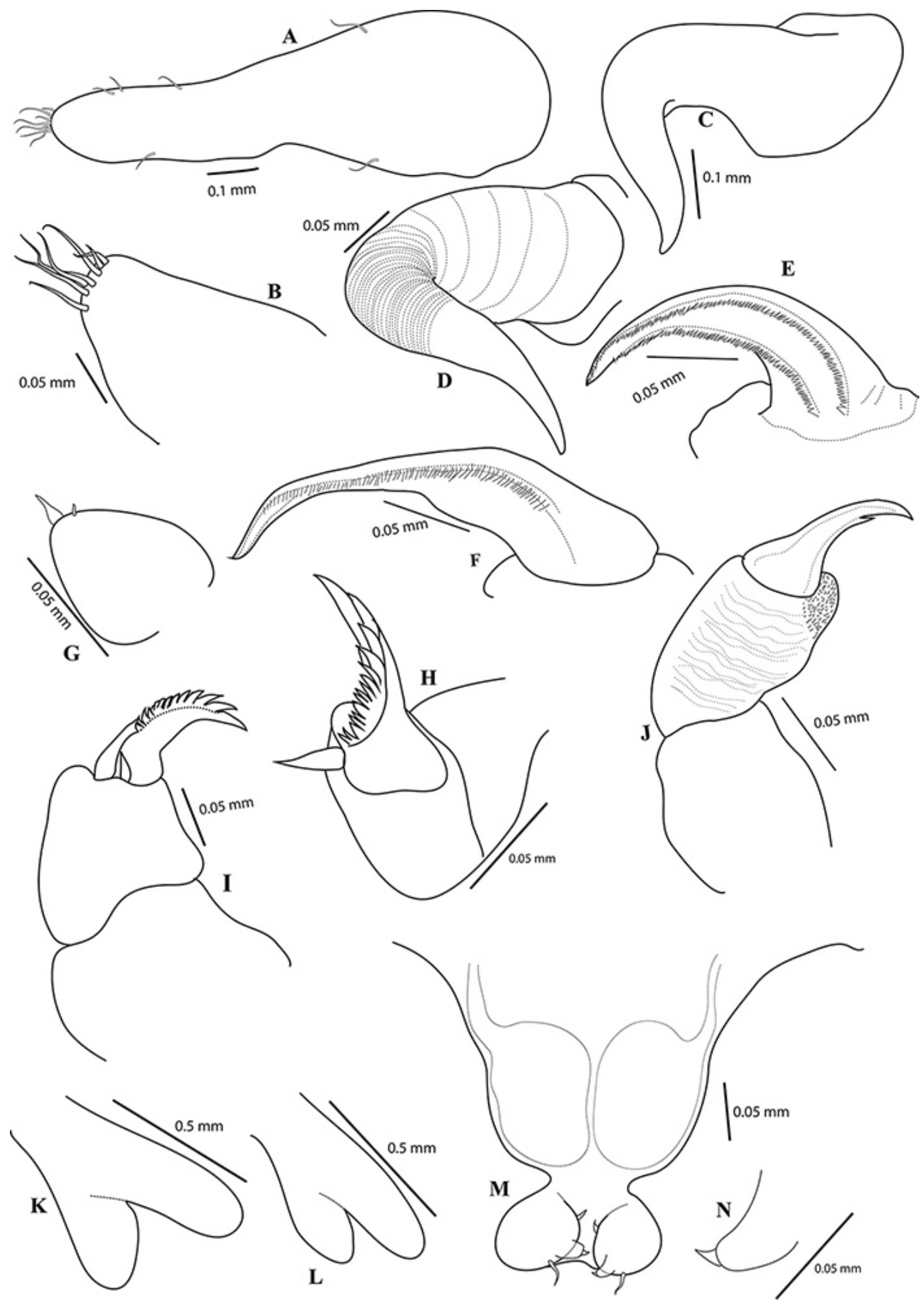

$\mathbf{L}$

Figure 10. Chondracanthus kabatai sp. n., non-type female from Zenopsis conchifer Lowe. A. Antennule. B. Antennule apex. C, D. Antenna. E, F. Mandible. G. Maxillule. H, I. Maxilla. J. Maxilliped. K. Leg 1. L. Leg 2. M. Ventral view of genito-abdomen. N. Caudal ramus. 

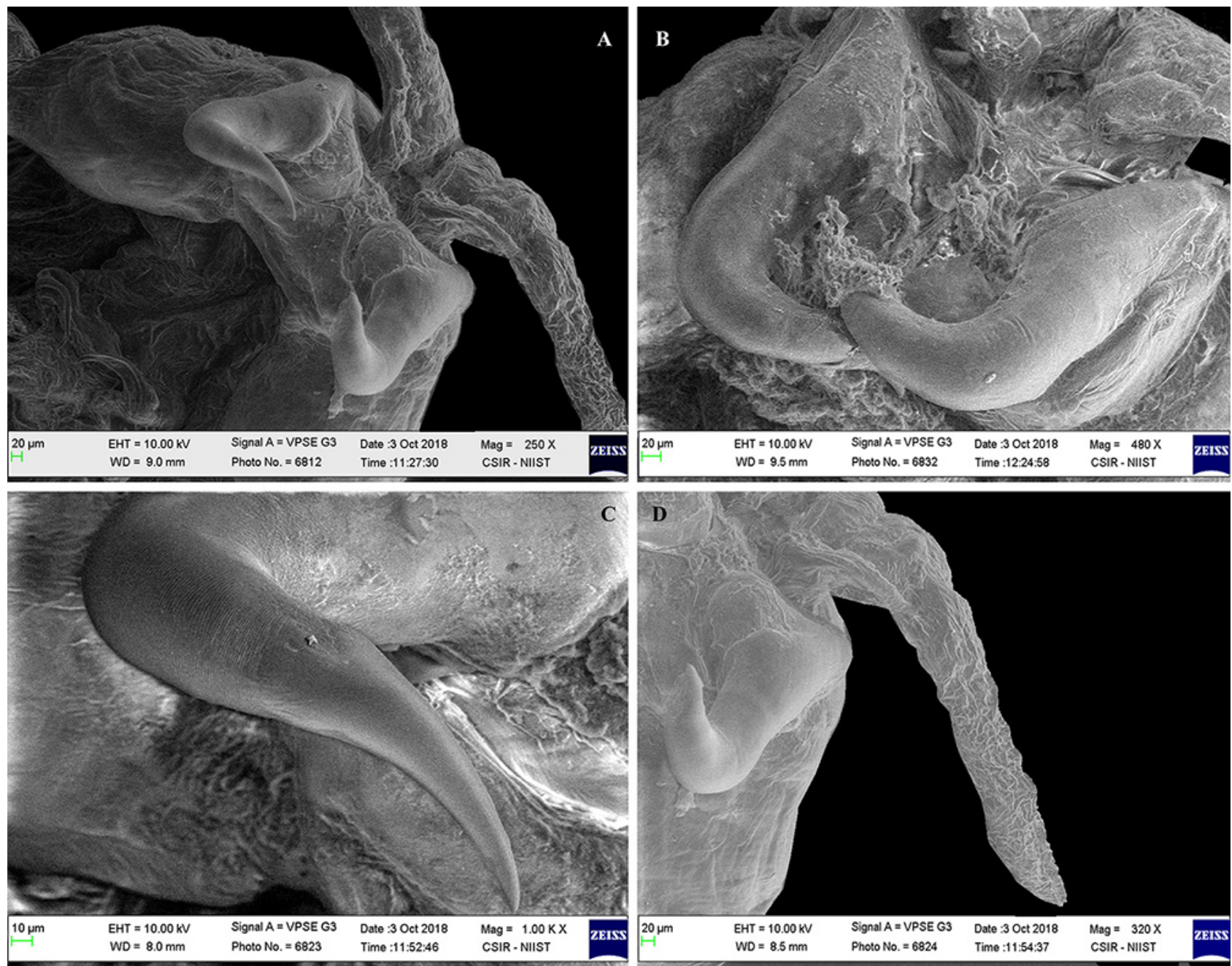

Figure 11. Scanning electron micrographs of Chondracanthus kabatai sp. n., non-type female from Zenopsis conchifer Lowe. A. Head ventral view showing antennule and antenna. B, C. Antenna. D. Antennule.

Male (Figs. 13-14): Body 0.4-0.5 mm long (including caudal rami), $0.23 \mathrm{~mm}$ wide, curved ventrally, cephalothorax, more than half length of total body; metasome cylindrical, with indistinct metamerism. Genital segment with pair of ventral genital ridges. Caudal ramus directed posteriorly.

Antennule elongated, with armature formula 1 and 7-8. Antenna, robust, strongly curved, sharp claw. Mandible with 16-20 teeth on convex side and 14-16 teeth on concave side. Maxillule with 2 setae. Maxilla without teeth on terminal process. Maxilliped article 2 with few denticles. Legs bilobate, legs 1 and 2 subequal, with a long lateral seta; endopods reduced to lobes.

Size. Ovigerous female (4.8-8.0 mm length).
Color: White after fixation, with yellow egg sac.

Host: Zenopsis conchifer Lowe.

Distribution: Known only from the type locality at Neendakara, Southwest coast, India.

Site of attachment: Attached to the floor of the buccal cavity, over the gill.

Etymology: This species is named in honor of recently deceased Prof. Zbigniew Kabata, one of the pioneer researchers on parasitic copepods of fish and world-renowned fish parasitologist. 

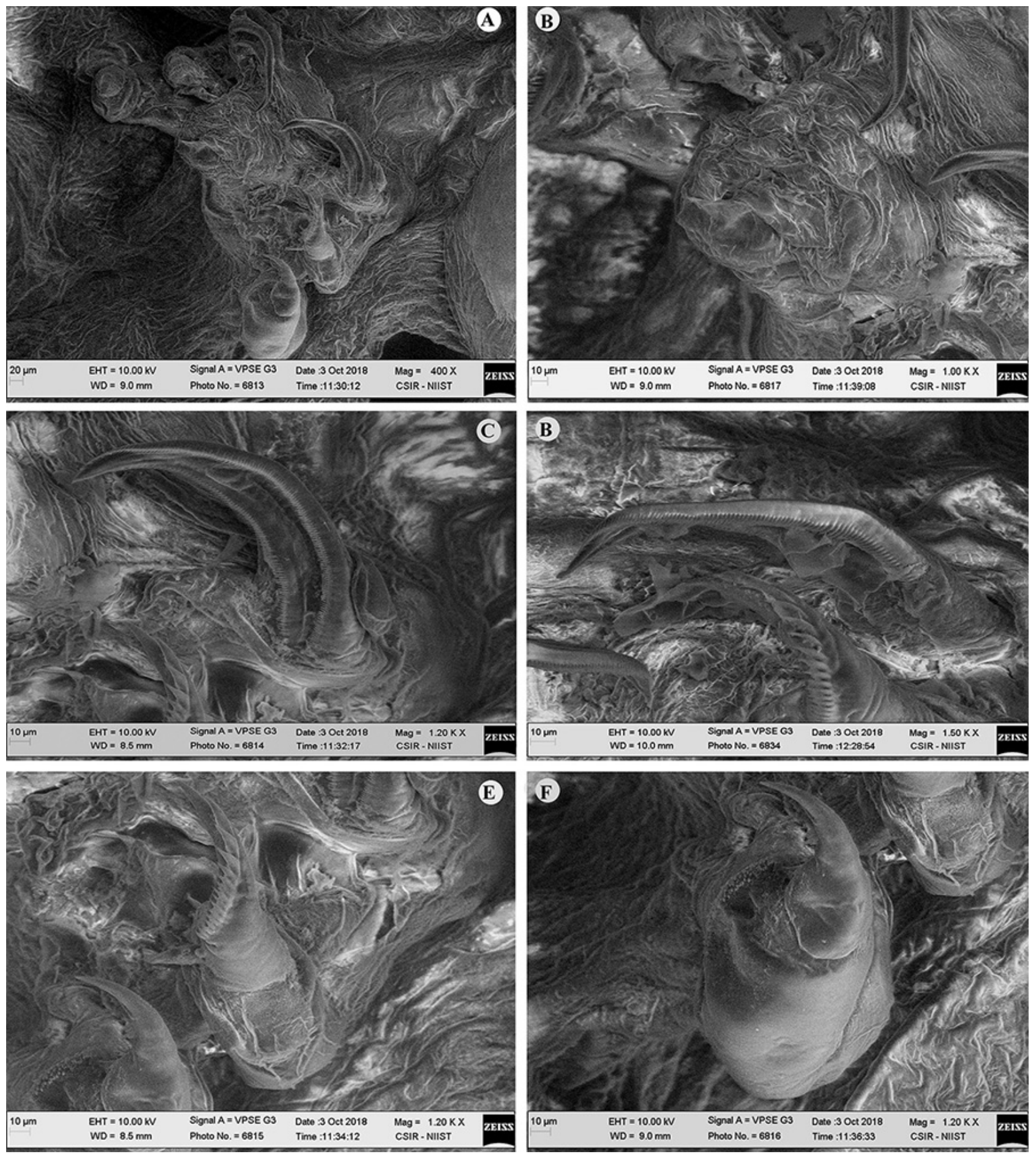

Figure 12. Scanning electron micrographs of Chondracanthus kabatai sp. n., non-type female from Zenopsis conchifer Lowe. A, B. Cephalic appendages. C, D. Mandible. E. Maxilla. F. Maxilliped. 

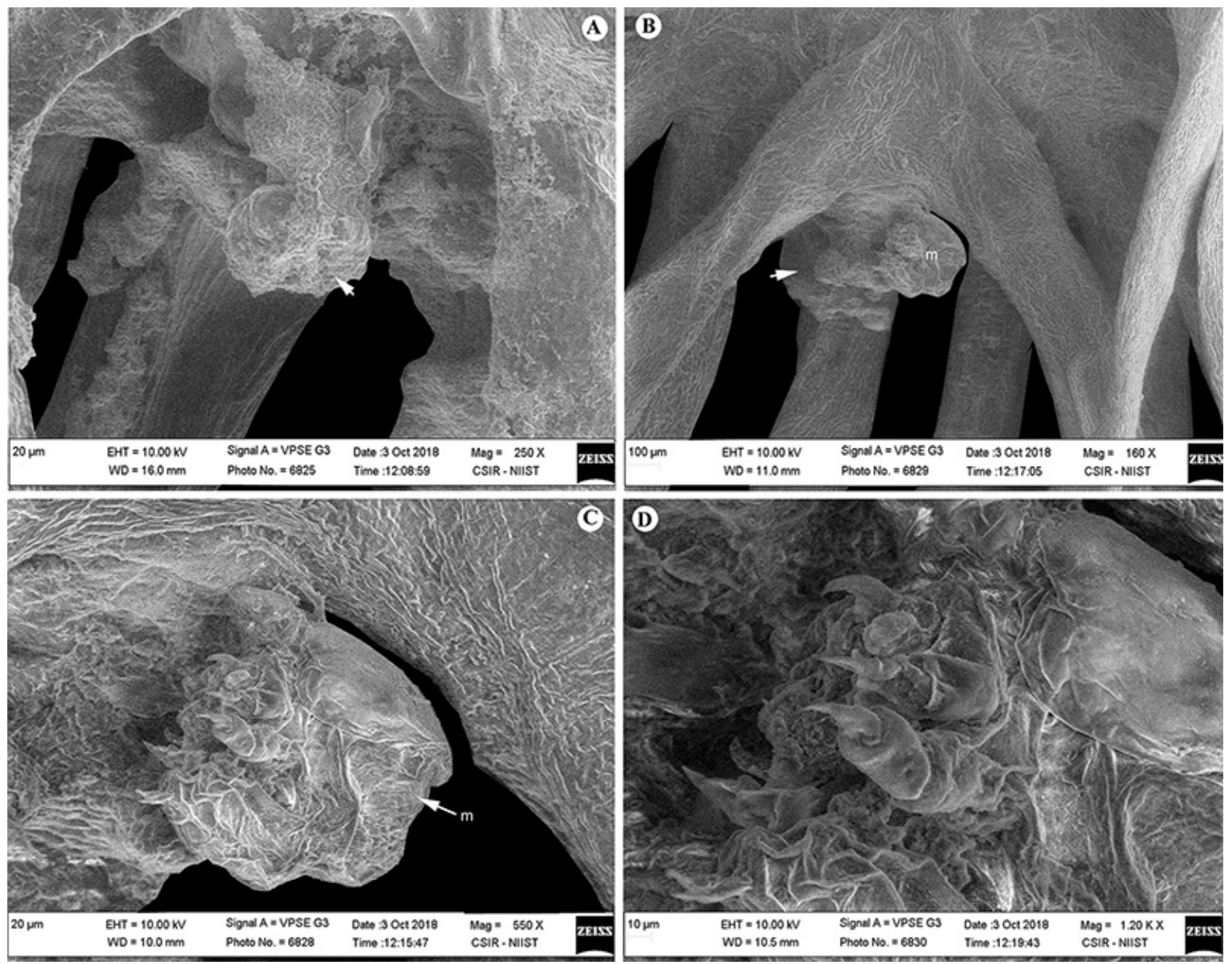

Figure 13. Scanning electron micrographs of Chondracanthus kabatai sp. n. from Zenopsis conchifer Lowe. A. Genito-abdomen ventral view (arrow). B-D. Male attached to genito-abdomen of female. (m- male)

\section{Discussion}

The family Chondracanthidae H. Milne Edwards, 1840 , can be recognized by the following combination of characters: body segmentation largely concealed, cephalon, with or without processes, not fused with any of the trunk segments; neck formed from first two pedigerous segments, trunk with or without processes; genital segment and abdomen fused; antennule fleshy and the antenna is strongly prehensile; two pairs of highly modified, fleshy and bi-or trilobate legs; dwarf male attached to the genito-abdomen of female (Ho, 1970; Kabata, 1979; Pillai, 1985; Ho and Kim, 1995; Cantatore and Timi, 2010).

Ho (1970) revised the family by excluding 12 old genera and also provided the key to the remaining 30 valid genera. Later, another 12 new genera have been erected by various authors and a revised key for 42 genera has been provided by Ho (1994), two among them later became synonyms. After Ho (1994), another eight new genera (viz., Argentinochondria Etchegoin, Timi and Sardella, 2003, Bactrochondria Ho, Kim and Kumar, 2000, Bereacanthus Huys, 2009, Bobkabata Hogans and Benz, 1990, Brasilochondria Thatcher and Pereira Júnior, 2004, Parapercicola Ho, Liu and Lin, 2011, Pseudolernentoma Luque and Alves, 2003, Ttetaloia Uyeno and Nagasawa, 2012) were erected and three older genera (viz., Immanthe LeighSharpe, 1934, Lernaeosolea Wilson 1944, Pharodes Wilson C.B., 1935) were restored. Now the family Chondracanthidae includes 51 valid genera, among them only four genera were previously known from India. With the current description of two new species, the genera Acanthochondria Oakley, 1930 and Chondracanthus Delaroche, 1811 are also represented in fishes of the Indian coastline. The list of current species of Chondracanthidae, its host fishes and distribution records are presented in Tab. 1. 


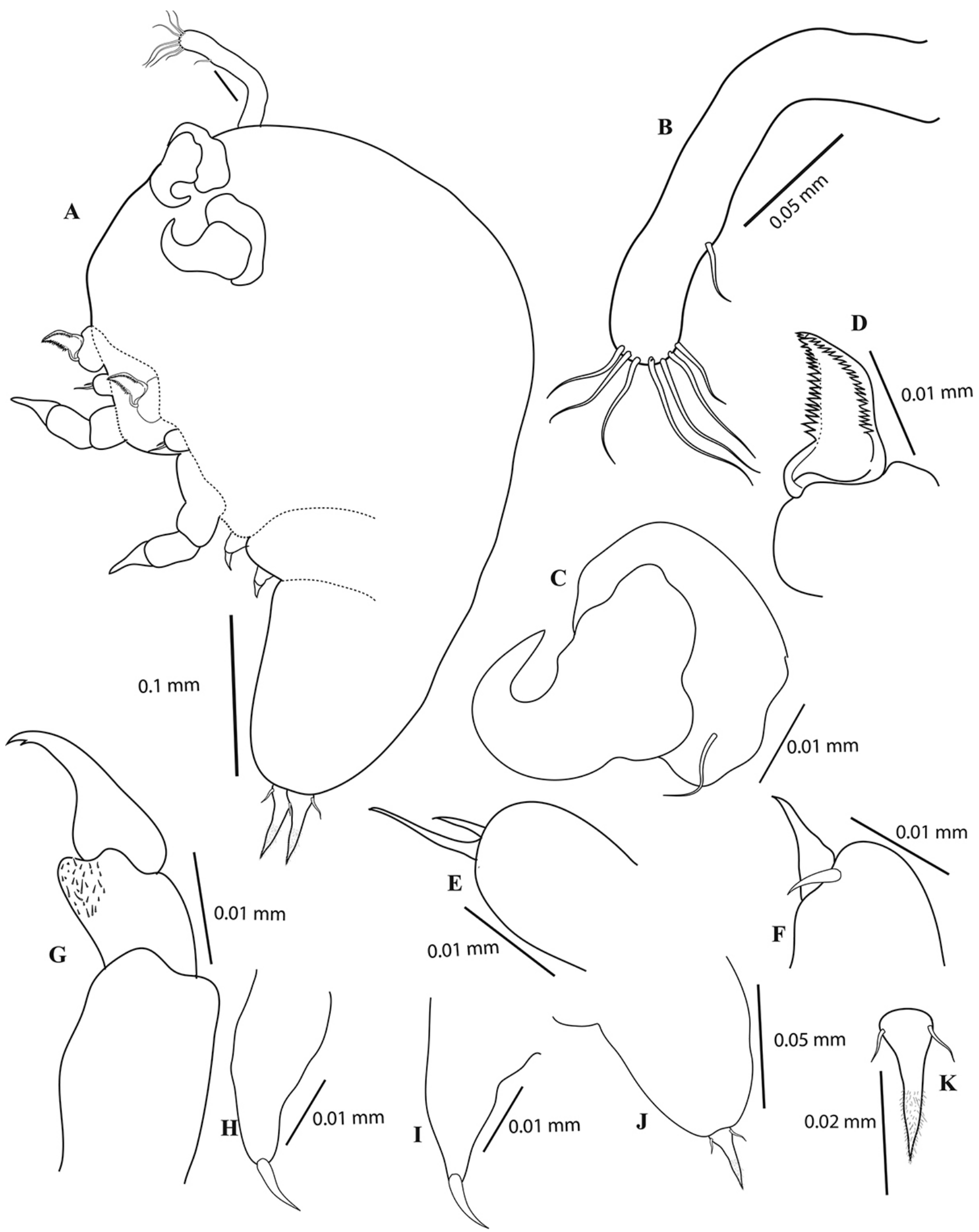

Figure 14. Chondracanthus kabatai sp. n., paratype male from Zenopsis conchifer Lowe. A. Habitus, lateral view. B. Antennule. C. Antenna. D. Mandible. E. Maxillule. F. Maxilla. G. Maxilliped. H. Leg 1. I. Leg 2. J. Lateral view of genito-abdomen. K. Rami. 
Table 1. List of chondracanthid copepods from India, with their fish hosts and distribution records.

\begin{tabular}{|c|c|c|c|c|c|c|}
\hline \multicolumn{4}{|c|}{ Chondracanthid copepods } & \multirow[t]{2}{*}{ Host fish [Family] } & \multirow[t]{2}{*}{ Localities in India } & \multirow[t]{2}{*}{ References } \\
\hline Genus & spec & & Synonyms & & & \\
\hline $\begin{array}{l}\text { Acanthochondria } \\
\text { Oakley, } 1930\end{array}$ & 1 & A. krishnai sp. $\mathrm{n}$. & & $\begin{array}{l}\text { Uranoscopus guttatus Cuvier } \\
\text { [Uranoscopidae] }\end{array}$ & $\begin{array}{l}\text { Muttom (the type } \\
\text { locality) and Colachel, } \\
\text { off South-west coast, } \\
\text { India; Neendakara, } \\
\text { Quilon, Kerala coast. }\end{array}$ & Present study \\
\hline \multirow[t]{2}{*}{$\begin{array}{l}\text { Bactrochondria Ho, } \\
\text { Kim and Kumar, } \\
2000\end{array}$} & 2 & $\begin{array}{l}\text { B. papilla Ho, Kim } \\
\text { and Kumar, } 2000\end{array}$ & & $\begin{array}{l}\text { Cynoglossus dubius (Regan) } \\
\text { [Cynoglossidae ] }\end{array}$ & Kerala & Ho et al., 2000 \\
\hline & 3 & B. hoi (Pillai, 1985) & $\begin{array}{l}\text { Ceratochondria hoi } \\
\text { Pillai, } 1985\end{array}$ & $\begin{array}{l}\text { Cynoglossus lida (Bleeker) } \\
\text { [Cynoglossidae }]\end{array}$ & Kerala & $\begin{array}{l}\text { Pillai, 1985; } \\
\text { Ho et al., } 2000\end{array}$ \\
\hline $\begin{array}{l}\text { Chondracanthus } \\
\text { Delaroche, } 1811\end{array}$ & 4 & C. kabatai sp.n. & & $\begin{array}{l}\text { Zenopsis conchifer Lowe } \\
\text { [Zeidae ] }\end{array}$ & $\begin{array}{l}\text { Neendakara (type } \\
\text { locality), Quilon, } \\
\text { Southern Coast, India }\end{array}$ & Present study \\
\hline \multirow[t]{4}{*}{$\begin{array}{l}\text { Heterochondria Yu, } \\
1935\end{array}$} & 5 & $\begin{array}{l}\text { H. petila Ho, Kim } \\
\text { and Kumar, } 2000\end{array}$ & & $\begin{array}{l}\text { Pseudorhombus javanicus } \\
\text { (Bleeker), P. triocellatus } \\
\text { (Bloch), P. arsius (Hamilton) } \\
\text { [Paralichthyidae] }\end{array}$ & Kerala & Ho et al., 2000 \\
\hline & 6 & H. pillai Ho, 1970 & & $\begin{array}{l}\text { Cynoglossus lida (Bleeker) } \\
\text { and C. dubius (Regan) } \\
\text { [Cynoglossidae], } \\
\text { Pseudorhombus javanicus } \\
\text { (Bleeker), P. triocellatus (Bloch), } \\
\text { P. elevatus Ogilby, and P. arsius } \\
\text { (Hamilton) [Paralichthyidae] }\end{array}$ & Kerala & $\begin{array}{l}\text { Pillai, 1985; Ho et al., } \\
2000\end{array}$ \\
\hline & 7 & $\begin{array}{l}\text { H. similis (Yu and } \\
\text { Wu, 1932) }\end{array}$ & & $\begin{array}{l}\text { Crossorhombus azureus (Alcock) } \\
\text { [Bothidae] }\end{array}$ & Kerala & Ho et al., 2000 \\
\hline & 8 & $\begin{array}{l}\text { H. zebriae (Ho, Kim } \\
\text { I.H. and Kumar, } \\
\text { 2000) }\end{array}$ & $\begin{array}{l}\text { Acanthochondria } \\
\text { zebriae Ho, Kim } \\
\text { I.H. and Kumar, } \\
2000 \text { (Transferred } \\
\text { to Heterchondria by } \\
\text { Tang et al., 2010) }\end{array}$ & $\begin{array}{l}\text { Crossorhombus azureus (Alcock) } \\
\text { [Bothidae] }\end{array}$ & Kerala & Ho et al., 2000 \\
\hline $\begin{array}{l}\text { Medesicaste Krøyer, } \\
1863\end{array}$ & 9 & $\begin{array}{l}\text { M. penetrans Heller, } \\
1868\end{array}$ & & $\begin{array}{l}\text { Trigla sp., Trigla capensis } \\
\text { [= Chelidonichthys capensis } \\
\text { (Cuvier)] [Triglidae] }\end{array}$ & Kerala & Pillai, 1985 \\
\hline \multirow[t]{2}{*}{$\begin{array}{l}\text { Protochondracanthus } \\
\text { Kirtisinghe, } 1950\end{array}$} & 10 & $\begin{array}{l}\text { P. alatus (Heller, } \\
1868)\end{array}$ & $\begin{array}{l}\text { Chondracanthus } \\
\text { alatus Heller, } 1865 \\
\text { Protochondracanthus } \\
\text { psettodis Kirtisinghe, } \\
1950\end{array}$ & $\begin{array}{l}\text { Psettodes erumi (Bleeker and } \\
\text { Schneider) [Psettodidae] }\end{array}$ & $\begin{array}{l}\text { Kerala, } \\
\text { Tamil Nadu }\end{array}$ & $\begin{array}{l}\text { Pillai, 1985; Ho et al., } \\
\text { 2000; Kizhakudan et } \\
\text { al., } 2015\end{array}$ \\
\hline & 11 & $\begin{array}{l}\text { P. trilobatus (Pillai, } \\
\text { 1964) }\end{array}$ & $\begin{array}{l}\text { Chondracanthus } \\
\text { trilobatus Pillai, } 1964\end{array}$ & $\begin{array}{l}\text { Psettodes erumi (Bleeker and } \\
\text { Schneider) [Psettodidae] }\end{array}$ & $\begin{array}{l}\text { Kerala, } \\
\text { Tamil Nadu }\end{array}$ & $\begin{array}{l}\text { Pillai, 1985; Ho et al., } \\
\text { 2000; Kizhakudan et } \\
\text { al., } 2015\end{array}$ \\
\hline
\end{tabular}

Acanthochondria krishnai sp. n.: most species of Acanthochondria possess a short neck (Kabata, 1979; Ho and Kim, 1995; Cantatore and Timi, 2010). By having a very long neck (at least 12-14 times longer than wide) the female of $A$. krishnai sp. n. can be distinguished from most of its congeners. Only three species described earlier, such as $A$. helicoleni Cantatore and Timi, 2010, A. uranoscopi Ho and Kim, 1995 and A. diastema Kabata, 1965 exhibit these characteristics. The new species is well distinguished from most of its congeners by: a much elongated body, presence of a pair of long distal process on trunk, funnel shaped genito-abdomen complex. The new species differs from A. helicoleni and A. diastema in having (1) the neck indistinguishably fused into the trunk; (2) presence of a pair of long, slender postero-lateral processes; (3) presence of much longer legs. Acanthochondria krishnai sp. n. is very close to $A$. uranoscopi by the presence of a pair of long, slender postero-lateral processes and the elongated neck and trunk. But the new species is very distinct from $A$. uranoscopi in: the shape of genitoabdomen, it is longer than wide and funnel shaped; 
abdomen with the prominent process which extends to the posterior tip of caudal rami ( $v s$ wider than long in A. uranoscopi); presence of prominent constrictions on posterior half of the trunk ( $v s$ constrictions not visible in A. uranoscopi); the comparative size of trunk, wider in A. krishnai (vs comparatively narrower in $A$. uranoscopi); the leg 2 and the posterior processes in A. krishnai is comparatively larger than A. uranoscopi.

Chondracanthus kabatai sp. n.: Tang et al. (2007) provided a key to the species of Chondracanthus, which includes 39 valid species. Later Braicovich et al. (2013) described Chondracanthus hoi Braicovich, Lanfranchi, Incorvaia, Inés and Timi, 2013 from northern Argentina and very recently, Gomez et al. (2018) described another species Chondracanthus dibranchi Gómez, Aguirre-Villaseñor and MoralesSerna, 2018 from Eastern Central Pacific. With the addition of C. kabatai sp. n., the genus Chondracanthus now comprises 42 valid species. According to the latest keys to species of Chondracanthus by Tang et al. (2007), and its amendment by Gomez et al. (2018), the divergence within the genus is mainly based on certain key characters of the female, which includes: presence or absence and the number of cephalic processes; presence or absence of dorsal/ lateral/ventral outgrowths or processes on the trunk; relative length of processes; legs 1 and 2, unilobate/ bilobate/trilobate condition of legs 1 and 2 (Kabata, 1979; Boxshall and Halsey, 2004; Tang et al., 2007; Gomez et al., 2018). The new species C. kabatai can be separated from most of its congeners by having: the cephalon with two pairs of lateral processes; legs 1 and 2 bilobate; the trunk region with a pair of dorsal, horn-like processes, on either side close to the lateral margin; bearing more than two pairs of lateral processes; the abdomen not extended posteriorly. Braicovich et al. (2013) suggested that the close resemblance of $C$. distortus (collected from Zeus faber Linnaeus and Zenopsis nebulosa (Temminck and Schlegel) and C. hoi (from Z. conchifer) may be due to the phylogenetic relatedness of host fishes, i.e., zeids. Corroborating this observation, the present new species is also collected from a zeid fish, $Z$. conchifer. Chondracanthus kabatai n. sp. is closely related to $C$. distortus and C. hoi by having the two pairs of cephalic processes. Nevertheless, the new species C. kabatai can be differentiated from both $C$. distortus and C. hoi in having a pair of dorsal, long, horn-like processes (0.5 times as long as lateral processes), on either side close to the lateral margin on trunk (vs dorsal processes absent in C. hoi and short and bluntly rounded in C. distortus); the cephalic process, much elongated and the posterior process is almost twice as long as anterior one ( $v s$ processes are blunt, pedunculate in C. hoi and shorter and process 2 is sub-equal in length to process 1 in C. distortus); anterio-lateral processes twice as long as dorsal processes ( $v s$ absent in C. hoi and smaller in C. distortus); abdominal processes are invariably much elongated (both smaller as well as larger specimens $[4.8 \mathrm{~mm}-8 \mathrm{~mm}])$ (vs stout, robust and shorter in both C. distortus and C. hoi); egg strings, narrow, cylindrical, irregularly coiled and extremely longer than trunk ( $v s$ broad, comparatively shorter in C. hoi and uncoiled, broad and short in C. distortus).

\section{ACKNOWLEDgeMENTS}

PTA thankfully acknowledges the Dr. D.S. Kothari Post-Doctoral Fellowship (No.F.4-2/2006 (BSR)/ BL/16-17/0401; dated: 28 August 2017) awarded by University Grants Commission. We extend our sincere thanks to Dr. Uyeno Daisuke, for his valuable suggestions/discussions on the species identity during the later stage of the manuscript revision. Further, we gratefully acknowledge the effort made by the two anonymous reviewers for their critical reviewing of the manuscript and making valuable suggestions for the improvement of the manuscript.

\section{References}

Aneesh, P.T.; Helna, A.K.; Kumar, A.B. and Maran B.A.V. 2018. Redescription of Lernaeenicus stromatei Gnanamuthu, 1953 (Copepoda: Siphonostomatoida: Pennellidae) infesting the Black Pomfret Parastromateus niger (Bloch) from Indian waters. Zootaxa, 4482: 375-382.

Boxshall, G.A. and Halsey, S.H. 2004. An introduction to copepod diversity. London, The Ray Society, 966p.

Braicovich, P.E.; Lanfranchi, A.L.; Incorvaia, I.S. and Timi, J.T. 2013. Chondracanthid copepod parasites of dories (Zeiformes: Zeidae) with the description of a new species of Chondracanthus from waters off northern Argentina. Folia Parasitologica, 60: 359-364.

Burmeister, H. 1835. Beschreibungeinigerneuenoderwenigerbekannten Schmarotzerkrebe, nebstallgemeinen Betrachtungenuber die Gruppe; welchersieangehoren. Nova Acta Physico-Medica Academiae Caesareae Leopoldino- Carolinae Naturae 
Curiosorum (Acta der Kaiserlichen Leopoldinisch-Carolinischen Deutschen Akademie der Naturforscher), Halle, 17: 269-336, pls. XXIII, XXIV, XXIVA, XXV.

Cantatore, D.M.P. and Timi, J.T. 2010. Acanthochondria helicoleni sp. nov. (Copepoda, Chondracanthidae) parasitic on Helicolenus lahillei (Scorpaeniformes, Sebastidae) from Argentinean waters. Acta Parasitologica, 55: 386-391.

Delaroche, F. 1811. Sur des animaux vivant sur les branchies des poissons. Nouveau Bulletin des Sciences, Société Philomatique de Paris, 2: 270-272.

Etchegoin, J.A.; Timi, J.T. and Sardella, N.H. 2003. Argentinochondria patagonensis n. gen., n. sp. (Copepoda: Chondracanthidae) parasitic on Genypterus brasiliensis (Pisces: Ophidiidae) from Patagonia, Argentina. Journal of Parasitology, 89: 701-704.

Froese, R, and Pauly, D. 2020. FishBase version (03/2018). Available at: http://www.fishbase.org/ Accessed on February 2020.

Gnanamuthu, C.P. 1953. Three lernaeid copepods parasitic on South Indian fishes. Journal of Parasitology, 39: 14-21.

Gomez, S.; Villasenor, H.G. and Morales-Serna, F.N. 2018. A new species of Chondracanthus (Cyclopoida: Chondracanthidae) parasitic on deep-sea Dibranchus spongiosa (Lophiiformes: Ogcocephalidae) from the Eastern Central Pacific. Acta Parasitologica, 63: 375-385.

Heegaard, P.E. 1940. Some new parasitic copepods (Chondracanthidae and Lernaeopodidae) from western Australia. Videnskabelige Meddelelser fra Dansk Naturhistoriske Forening, Copenhagen, 104: 87-101, figs. 1-28.

Heller, C. 1865. Crustaceen. In: Reise der Osterreichischen Fregatte Novara um die Erde in den Jahren 1857, 1858, 1859. Zoologischer Theil, 2(3): 1-280, pls. 1-25.

Hogans, W.E. and Benz, G.W. 1990. A new family of parasitic copepods, the Lernaeosoleidae (Poecilostomatoida), from demersal fishes in the northwest Atlantic, with a description of Bobkabata kabatabobbus n. gen., n. sp. and a redescription of Lernaeosolea lycodis Wilson, 1944. Canadian Journal of Zoology, 68: 2483-2488

Ho, J.S. 1970. Revision of the genera of the Chondracanthidae, a copepod family parasitic on marine fishes. Beaufortia, 229: 105-218.

Ho, J.S. 1994. Chondracanthid copepods (Poecilostomatoida) parasitic on Japanese deep-sea fishes, with a key to the genera of the Chondracanthidae. Journal of Natural History, 28: 505 -517 .

Ho, J.S. and Kim, I.H. 1995. Acanthochondria (Copepoda: Chondracanthidae) parasitic on Fishes of Sado Island in the Sea of Japan, with a preliminary review of the genus. Report of the Sado Marine Biological Station, 25: 45-67.

Ho, J.H.; Kim, I.H. and Kumar, A.B. 2000. Chondracanthid copepods parasitic on flatfishes of Kerala, India. Journal of Natural History, 34: 709-735.

Ho, J.S.; Liu, W.C. and Lin, C.L. 2011. Two species of chondracanthid copepods (Poecilostomatoida) parasitic on sandperches of Taiwan. Crustaceana, 84:1635-1648.

Huys, R. 2009. Unresolved cases of type fixation, synonymy and homonymy in harpacticoid copepod nomenclature (Crustacea: Copepoda). Zootaxa, 2183: 1-99.

Kabata, Z. 1979. Parasitic Copepoda of British fishes. London, The Ray Society, 468p.
Kizhakudan, J.K.; Praveena, P.E.; Maran, B.A.V.; Otta, S.K.; Bhuvaneswari, T.; Rajan, J.J.S.; Krishnamoorthi, S. and Jithendran, K.P. 2015. Investigation on the mortality of juveniles in captive stock of the Indian halibut Psettodes erumei. Indian Journal of Geo-Marine Sciences, 44: 1217-1223.

Luque, J.L. and Alves, D.R. 2003. Pseudolernentoma brasiliensis n. g., n. sp. (Copepoda: Poecilostomatoida: Chondracanthidae) parasitic on Genypterus brasiliensis (Osteichthyes: Ophidiidae) from off the State of Rio de Janeiro, Brazil. Systematic Parasitology, 56: 195-199.

Leigh-sharpe, W.H. 1934. Anchistrotos laqueus n. sp. a parasitic copepod of Serranus cabrilla. Parasitology, 27: 266-269

Milne Edwards, H. 1840. Ordre des Copepodes. p. 411-529. In: Histoire naturelle des Crustaces, comprenant l'anatomie, la physiologie et la classification de ces animaux. Vol. 3. Paris, Librairie Encyclopédique de Roret.

Müller, O.F. 1776. Zoologiæ Danicæ Prodromus, seu Animalium Daniæ et Norvegiæ indigenarum characteres, nomina, et synonyma imprimis popularium. Havniæ [Copenhagen]: Hallageri, xxxii $+274 \mathrm{p}$.

Oakley, C.L. 1930. The Chondracanthidae (Crustacea: Copepoda); with a description of five new genera and one new species. Parasitology, 22: 182-201.

Ohtsuka, S.; Nitta, M.; Nakamura, T. and Maekawa, Y. 2019. A new species of Lagochondria (Crustacea: Copepoda) parasitic on callionymid fish: first record of precopulatory mate guarding in fish-parasitic cyclopoid copepods, and of the occurrence of the genus in the North Pacific. Zoological Science, 36: 432-439.

Pillai, N.K. 1964. A miscellaneous collection of copepods parasitic on South Indian fishes. Journal of Marine Biological Association of India, 6: 61-83.

Pillai, N.K. 1985. The Fauna of India. Copepod Parasites of Marine Fishes. In: The Fauna of India. Zoological Society of India, Calcutta, 900p.

Rangnekar, M.P. 1960. Copepods parasitic on fishes of Bombay. 1. Lernaeopodoida. Journal of University of Bombay, 29: 198-200.

Sebastian, M.J. 1967. On a new species of Lernaeenicus, L. bataviensis (Copepoda-Lernaeidae) with a key for the identification of the Indian species. Proceedings of the Symposium on Crustacea. Symposium Series, Marine Biological Association of India, (2)1: 114-118, figs. 1-7.

Tang, D.; Andrews, M. and Cobcroft, J.M. 2007. The first chondracanthid (Copepoda: Cyclopoida) reported from cultured finfish, with a revised key to the species of Chondracanthus. Journal of Parasitology, 93: 788-795.

Tang, D.; Kalman, J.E. and Ho, J. S. 2010. Acanthochondria cyclopsetta Pearse, 1952 and A. alleni n. sp. (Copepoda; Cyclopoida; Chon- dracanthidae) from flatfish hosts of the U.S.A., with comments on the taxonomie position of $A$. zebriae Ho, Kim \& Kumar, 2000 and A. bicornis Shiino, 1955 and the validity of Pterochondria Ho, 1973. Zootaxa, 2657: 18-32.

Thatcher, V.E. and Joaber, P.J. 2004. Brasilochondria riograndensis gen. nov., sp. nov. (Copepoda, Chondracanthidae) a parasite of flounders of Rio Grande do Sul State, Brazil. Revista Brasileira de Zoologia, 21: 515-518.

Uyeno, D. and Nagasawa, K. 2012. Ttetaloia hoshinoi, a new genus and species of chondracanthid copepod (Poecilostomatoida) parasitic on triplefins (Actinopterygii: Tripterygiidae) from Japanese waters. Zoosymposia, 8: 39-48. 
Walter, T.C. and Boxshall, G. 2019. World of copepods database. Available at http://www.marinespecies.org/copepoda. Accessed on 06 June 2019.

Wilson, C.B. 1935. New parasitic copepods. In: Reports on the collections obtained by the first Johnson-Smithsonian deep-sea expedition to the Puerto Rican Deep. Smithsonian Miscellaneous Collection, 91:1-9, pls. 1-3.

Wilson, C.B. 1944. Parasitic copepods in the United States National Museum. Proceedings of the United States National Museum, 94: 529-582, pls. 20-34. 